Staphylococcus epidermidis to smooth surfaces. Infect Immun 1982;37:318-26.

${ }^{2}$ Peters G, Locci R, Pulverer G. Adherence and growth of coagulase negative staphylococci on surfaces of intravenous catheters. $J$ Infect Dis 1982;146:479-82.

${ }^{3}$ Kristinsson KG, Hastings JGM, Spencer RC. Coagulase negative staphylococcal infections. Br Med J 1985;290:1743.

"Peters G, Pulverer G. Pathogenesis and management of Staphylococcus epidermidis "plastic" foreign body infections. J Antimicrob Chemother 1984 (Suppl D);14:67-71.

\section{Commercial strip test for reduction of nitrate by bacteria}

The ability of an organism to reduce nitrate is commonly tested by the Griess-Ilosvay method. ${ }^{1}$ This entails two reagent mixtures, one of which contains naphthylamine, a potentially harmful chemical. An alternative is the Cook plate method, in which the organism is stab inoculated on a blood agar plate containing nitrate. ${ }^{2}$ The reaction in the plate test is irreversible and is unaffected by any subsequent reduction of the nitrite. The zones of discolouration caused by the formation of methaemoglobin are, however, often indistinct, and the plate may require 48 hours of incubation. As an alternative to these methods we evaluated a commercial strip designed to screen for clinically important bacteriuria by detecting nitrite derived from dietary metabolites (Ames Division, Miles Laboratories). In this test the nitrite reacts with p-arsanilic acid to form a diazonium compound that is coupled with 1,2,3,4-tetrahydrobenzo(h)-quinoline3-ol to produce a pink colour.

\section{Material and methods}

A nitrate broth was prepared containing potassium nitrate (nitrite free) $0.3 \%$ and tryptone (Oxoid L42) $0.5 \% \mathrm{w} / \mathrm{v}$ in distilled water. The broth was distributed in $3 \mathrm{ml}$ volumes in bijoux bottles and autoclaved at $115^{\circ} \mathrm{C}$ for 10 minutes.

Table Nitrate reductase: results for eight bacterial strains using three different methods

\begin{tabular}{|c|c|c|c|c|c|}
\hline \multirow{3}{*}{ Organism } & \multicolumn{5}{|c|}{ Nitrate reduction test } \\
\hline & \multicolumn{2}{|c|}{ Cook plate } & \multicolumn{2}{|c|}{ Commercial strip } & \multirow{2}{*}{$\begin{array}{l}\text { Griess-Ilosvay } \\
\text { test } \\
24 \text { hour }\end{array}$} \\
\hline & 24 hour & 48 hour & 4 hour & 24 hour & \\
\hline $\begin{array}{l}\text { Coagulase negative Staphylococcus } \\
\text { Coagulase negative Staphylococcus } \\
\text { Acinetobacter lwoffi } \\
\text { Acinetobacter lwoffi } \\
\text { Pseudomonas aeruginosa (four strains) }\end{array}$ & $\begin{array}{l}- \\
- \\
- \\
+\end{array}$ & $\begin{array}{l}+ \\
+ \\
+ \\
+\end{array}$ & $\begin{array}{l}+ \\
+ \\
+ \\
+\end{array}$ & $\begin{array}{l}+ \\
+ \\
+ \\
+ \\
-\end{array}$ & $\begin{array}{l}+ \\
+ \\
+ \\
+ \\
+\end{array}$ \\
\hline
\end{tabular}

Clinical isolates from a representative range of nitrate positive and nitrate negative genera were collected. For the test a broth was inoculated from a fresh subculture to give a density of about $10^{8}$ colony forming units $/ \mathrm{ml}$. After incubation at $37^{\circ} \mathrm{C}$ the broth was tested for the presence of nitrite at 4 hours and again at 24 hours using the commercial strips. A strip was immersed in the broth, immediately removed, drained on the inside of the container, and read at 40 seconds, as recommended for urine testing by the manufacturer (Technical information, Miles Laboratories). Any degree of pink colour was regarded as a positive test. At 24 hours the broth was tested for nitrate by a modified Griess-Ilosvay method. Broth $(200 \mu \mathrm{l})$ was pipetted into a microtitre well, and $50 \mu \mathrm{l}$ of $0.8 \%$ sulphanilic acid and $0.5 \%$ Cleve's acid, dimethyl- $\alpha$-naphthylamine, added. A pink colour indicated the reduction of nitrate to nitrite. If no colour change occurred the test was repeated in a well containing about $30 \mathrm{mg}$ of zinc dust. ${ }^{3}$ Development of a pink colour at this stage indicated that the nitrate had not been reduced by the test organism, whereas absence of colour indicated total breakdown of nitrate and nitrite. All strains were tested by the Cook plate method using a paper strip impregnated with potassium nitrate and incubated for up to 48 hours. $^{2}$

\section{Results}

Fifty eight of the 66 strains tested showed concordance of the commercial strip method, Cook plate, and modified GriessIlosvay method at 24 hours. The 58 strains included: Nitrate positive (1): Ecoli (5), Klebsiella (4), Haemophilus (6), Enterobacter (2), Proteus (4), Saureus (5), Actinomyces (3), and Branhamella catarrhalis (3); Nitrate negative (1): Listeria (5), Bordetella (2), Flavobacterium (2), Lactobacillus (5), and $A$ anitratum (12). The Table shows the results given by the other eight strains.

When tested by the strip method 63 of the 66 organisms gave the appropriate nitrate reaction $^{1}$ at four hours, and the other three 
virus were, indeed, present in the serum, and specific IgM was detected by radioimmunoassay. ${ }^{4}$ The other subject had no record of any recent clinical symptoms. His serum had traces of DNA and was negative for IgM and IgG.

Antibodies shown by immunoelectroosmophoresis were found in about $25 \%$ of the contacts of the two antigen positive subjects. A similar prevalence of human parvovirus infection has been observed in the general population (study in preparation). We must point out, however, that the lack of a follow up on the antibodies in the subjects does not prove that this high incidence of viraemia was related to human parvovirus outbreaks in the two units at that time.

The detection in serum of antigen and antibody at the same time, although uncommon, is of some interest and adds evidence to some previous observations on the persistence of the human parvovirus antigenemia during the initial phase of the humoral response. ${ }^{45}$ Immunocomplex deposits cause damage leading to a variety of syndromes and some of them, such as rashes and arthralgia, may follow infection with parvovirus. ${ }^{1}$ It would be interesting to find associations between immune complexes and the clinical course of the disease. Assays of circulating human parvovirus immune complexes in acute and early convalescent serum samples may provide useful information.

The DNA and IgM and IgG tests were performed in the department of medical microbiology, University College Hospital, London.

We thank Dr MJ Anderson for providing virus, reference sera, and research facilities.

O BARTOLOMEI CORSI

A AZZI

Institute of Microbiology, University of Florence, Viale Morgagni 48,

References 50134 Florence, Italy

${ }^{1}$ Anderson MJ, Pattison JR. The human parvovirus. Arch Virol 1984;82:137-48.

${ }^{2}$ Siegl G, Bates RC, Berns KI, et al. Characteristics and taxonomy of parvoviridae. Intervirology 1985;23:61-73.

${ }^{3}$ Anderson MJ, Jones SE, Minson AC. Diagnosis of human parvovirus infection by dot-blot hybridisation using cloned viral DNA. $J$ Med Virol 1985;15:163-72.

${ }^{4}$ Cohen BJ, Mortimer PP, Pereira MS. Diagnostic assays with monoclonal antibodies for the human serum parvovirus-like virus (SPLV). $J$ Hyg 1983;91:113-30.

${ }^{5}$ Pattison JR, Jones SE, Hodgson J, et al. Parvovirus infections and hypoplastic crisis in sikle-cell anemia. Lancet 1981;i:664-5.
Survival of Bordetella pertussis in transport media

Concern has been repeatedly expressed over the low isolation rates of B pertussis from clinical cases of whooping cough. ${ }^{1-3}$ Poor recovery from pernasal swabs is thought to be due to previous immunisation, ${ }^{1}$ faulty swabbing technique, ${ }^{4}$ or retention of the organism on the swab. ${ }^{5}$ This study was performed to determine what effect the transport media used had on the survival of the organism.

$A$ heavy suspension of the laboratory stock strain of Bpertussis was made in saline. Forty two cotton wool pernasal swabs (Medical Wire and Equipment) were then dipped into this suspension. Fourteen swabs were replaced into their plastic tubes (dry swabs). The ends of the remaining swabs were cut off and half of them placed into bijoux bottles of Amies' transport medium (Difco Laboratories); the other half were placed into a similar container of Stuart's transport medium (Oxoid). All the swabs were left on the open bench for one, two, four, eight, twenty four, forty eight, or ninety six hours. At the appropriate time the swabs were transferred to $1 \mathrm{ml}$ of sterile physiological saline in a bijoux bottle and shaken vigorously for thirty seconds on a bench shaker. Miles and Misra counts ${ }^{6}$ were then performed on the resulting suspension on Bordet-Gengou medium and the plates incubated at $37^{\circ} \mathrm{C}$ for three days before counting.

Table 1 shows the mean viable count of
$B$ pertussis recovered from the swabs at various times. The counts on the dry swabs were higher for the first four hours than those of the swabs in Stuart's or Amies' media. After four hours the counts fell most rapidly on the swabs in Stuart's medium but less rapidly on the dry swabs. The counts on the swabs in Amies' medium, however, remained high after ninety six hours when the other swabs yielded no growth.

Table 2 shows the decimal reduction times of the viable counts calculated from the linear regression curves over twenty four, forty eight, and ninety six hours. The decimal reduction times were consistently higher in Amies' medium and lower in Stuart's medium.

The results of this study suggest that if a pernasal swab can be transported to the laboratory within four hours transport medium is unnecessary. If the swab is likely to be delayed for more than four hours Amies' transport medium should be used rather than Stuart's transport medium.

PR HUNTER Public Health Laboratory, University Hospital of Wales, Cardiff CF $4 \mathrm{XW}$.

\section{References}

${ }^{1}$ Public Health Laboratory Service Working Party. Diagnosis of whooping cough: com parisons of serological tests with isolation Bordetella pertussis. A combined Scottis study. Br Med J 1970;IV:637-9.

${ }^{2}$ Lewis FA, Gust ID, Bennett NMcK. On the aetiology of whooping cough. J Hyg 1973;71:139-44.

Table 1 Mean viable counts of $B$ pertussis on pernasal swabs at various intervals after inoculation

\begin{tabular}{llll}
\hline $\begin{array}{l}\text { Time after inoculation } \\
\text { (hours) }\end{array}$ & \multicolumn{2}{l}{ Transport conditions } \\
\cline { 2 - 4 } & Dry & Stuart's & Amies' \\
\hline 1 & $3.5 \times 10^{6}$ & $1 \cdot 2 \times 10^{6}$ & $1.2 \times 10^{6}$ \\
2 & $2 \cdot 1 \times 10^{6}$ & $3.5 \times 10^{6}$ & $6.5 \times 10^{5}$ \\
4 & $2 \cdot 3 \times 10^{6}$ & $1.3 \times 10^{6}$ & $1.5 \times 10^{6}$ \\
8 & $7 \cdot 3 \times 10^{4}$ & $3.8 \times 10^{4}$ & $2.6 \times 10^{5}$ \\
24 & $3.9 \times 10^{4}$ & $1 \times 10^{2}$ & $1.8 \times 10^{6}$ \\
48 & $4 \cdot 1 \times 10^{2}$ & 25 & $1.8 \times 10^{6}$ \\
96 & $0<25$ & $0<25$ & $5.0 \times 10^{5}$ \\
\hline
\end{tabular}

Table 2 Decimal reduction times of viable counts of $B$ pertussis

\begin{tabular}{llll}
\hline $\begin{array}{l}\text { Calculated over } \\
\text { initial time (hours) }\end{array}$ & \multicolumn{2}{l}{ Transport conditions } & \\
\cline { 2 - 4 } & Dry & Stuart's & Amies' \\
\hline 24 & $9 \cdot 3$ & $5 \cdot 1$ & 16.5 \\
48 & 12.0 & $7 \cdot 7$ & 23.0 \\
96 & & & 37.6 \\
\hline
\end{tabular}

